\title{
İkna Edici Illetişimde Reklam Müziğinin Kullanımı: Banka Reklam Müziklerinin İkna Edici İletişim Stratejileri Açısından İncelenmesi
}

\author{
Nuray Yılmaz Sert (Doç. Dr.) \\ Manisa Celal Bayar Üniversitesi İletişim Fakültesi \\ nuray.ylmz@gmail.com \\ Orcid: 0000-0002-5329-5469 \\ Tuba Çevik Ergin (Dr. Öğr. Üyesi) \\ Sakarya Üniversitesi İletişim Fakültesi \\ tubacevikergin@sakarya.edu.tr \\ Orcid: 0000-0002-4632-7987 \\ Ebru Yılmaz \\ ebruyilmazparoz@gmail.com \\ Orcid: 0000-0002-7243-7928
}
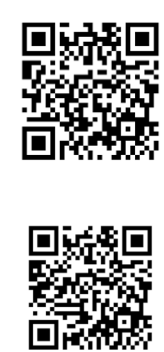

Başvuru Tarihi: 03.06.2018

Yayına Kabul Tarihi: 09.01.2019

Yayınlanma Tarihi: 21.01.2019

\section{Öz}

İkna, bir takım iletişim taktikleri yoluyla insanları zor kullanmadan belirli davranışlara yönlendirme sanatı olarak tanımlanmaktadır. İknaya ilişkin yapılan çalışmalar hem akla hem duygulara hitap eden mesajların, alıcıda istenilen davranışın ortaya çıkmasında, daha etkili olduğunu ortaya koymaktadır. Bu bağlamda, tüketicilerde satın alma davranışı oluşturmayı amaçlayan reklam mesajlarının duygulara hitap etme yoluyla anlamını güçlendirmek ve etkinliğini artırabilmek için çoğunlukla müzikten yararlandığı görülmektedir. Müzik, duyguları harekete geçirdiği için reklamcılık sektöründe önemli bir yer tutmaktadır. İnsanlarda duyguları yoğunlaştıran reklam müzikleri bir yandan reklamın beğenilmesini sağlarken öte taraftan markanın akılda kalıcılığına da katkıda bulunmaktadır. Akılda kalıcı olmayı başaran reklam müziklerinin hedef kitle tarafından yıllar sonra bile hatırlandığı bilinmektedir.

Bu çalışmanın amacı; Türkiye'nin marka değeri en yüksek bankalarının televizyon reklam film müziklerinin ikna edici iletişim açısından bir analizini ortaya koymak ve reklamlarda müziğin kullanımına ilişkin stratejilerin ikna stratejileriyle örtüşüp örtüşmediğini belirlemektir. Bu amaç doğrultusunda bağımsız marka değerleme ve strateji danışmanlık Şirketi Brand Finance'ın, "Dünyanın En Değerli 500 Banka Markası - 2017” araştırmasının sonuçlarına göre listeye giren 9 Türk bankası araştırmanın örneklemi olarak belirlenmiştir. Araştırma yöntemi olarak ise; 30 Ocak 2018 tarihi itibarıyla bu bankaların yayında olan son televizyon reklam filmleri belirlenmiş ve içerik analizi yöntemiyle incelenmiștir.

Anahtar Kelimeler: Reklam, Müzik, İkna, Banka, İletişim. 


\title{
Use of Advertising Music in Persuasive Communication: Analyzing of Banking Advertising Music in Terms of Persuasive Communication Strategies
}

\author{
Nuray Yılmaz Sert (Assoc. Prof. Dr.) \\ Manisa Celal Bayar University Faculty of Communication \\ nuray.ylmz@gmail.com \\ Orcid: 0000-0002-5329-5469 \\ Tuba Çevik Ergin (Asst. Prof. Dr.) \\ Sakarya University Faculty of Communication \\ tubacevikergin@sakarya.edu.tr \\ Orcid: 0000-0002-4632-7987 \\ Ebru Yılmaz \\ ebruyilmazparoz@gmail.com \\ Orcid: 0000-0002-7243-7928
}

Date Received: 03.06.2018

Date Accepted: 09.01.2019

Date Published: 21.01.2019

\begin{abstract}
Persuasion is defined as the art of leading people to certain behaviors without difficulty through some communication tactics. The studies related to persuasion reveal that messages that appeal to both mind and emotions are more effective in for the desired behavior of the receiver. In this context, it has been seen that advertising messages, for the aiming to create purchasing behavior of the consumers, mostly use music to enhance the meaning and the efficiency of appealing to emotions. Music takes an important place in the advertising industry because it affects emotions. Advertising music, which stimulates the emotions of the human, helps to make the advertisement admirable while it also contributes to the remembrance of the brand. It is known that the advertising musics have succeeded in keeping in mind are remembered by the target audience even after many years.

The purpose of this study is to analyze the musics of the television advertising of the highest brand valued banks in Turkey for the persuasive communication and to determine whether the strategies relative to using musics in advertising match to persuasion strategies. For this purpose, 9 Turkish banks that entered the list according to the results of the independent brand valuation and strategy consultancy Company Brand Finance 's "The Most Valuable 500 Bank Markets of the World - 2017" survey were determined as the sample of the research. As a research method; as of January 30th, 2018, the latest television advertising of these banks have been identified and analyzed by the content analysis.
\end{abstract}

Keywords: Advertising, Music, Persuasion, Bank, Communication. 


\section{Giriş}

Beklenilen sonuçları reklamveren tarafından bilinçli olarak oluşturulan ve yönlendirilen reklamların amacı hedef kitlenin algı, öğrenme ve benimseme süreçlerinde bilinçli bir etki yaratarak sonuçta davranışlarının değişmesini sağlamaktır. İkna ediciliği reklamın diğer iletişim türlerine göre en baskın özelliği olarak belirtilebilir (Babacan,2015,47). Reklamlar ikna ediciliği artırabilmek için çeşitli taktik ve araçlar kullanmaktadır. Reklamlarda iknayı artırmak için kullanılan en önemli araçlardan birisi ise reklam müzikleridir. Bilgi, duygu ve düşüncelerin aktarılmasında reklam müziklerinden sıklıkla yararlanıldığı görülmektedir. Reklam müziklerinin beğenilmesi, reklamın da tekrar tekrar izlenilmesini sağlamaktadır. Akılda kalıcı olmayı başaran reklam müzikleri yıllar sonra bile hatırlanabilmektedir. Örneğin; "Mutluluk deyince akla, hemen onun adı gelir, Eti, eti, eti...., "Hayat bana Waikiki vay vay..", "Çocuk da yaparım kariyer de..." vb. Pazarlama literatüründeki birçok çalışma, reklamcılıkta müzik kullanımının etkilerini araştırmaktadır. Araştırmalar, farklı koşullara bağlı olarak, müziğin iletişim etkinliğini artırabileceğini veya azaltabildiğini göstermektedir. Müziğin reklâm ve ürün üzerinde nasıl etki ettiğini gösteren temel faktörler şunlardır: a) Tüketicinin içinde bulunduğu farklı ilgilenim düzeyleri ve bilişsel veya duygusal süreçler, b) Tüketicinin, müziğin reklamın ana fikrine uygunluğuna ilişkin öznel algısı, c) müzikal unsurların organizasyonu. Tüketici ilgileniminin rolünü ve bilişsel süreç üzerindeki etkilerini vurgulayan a ve b müziğin ikna üzerindeki etkisini açıklamak için yaygın olarak kullanılmaktadır (Riley ve Anderson, 2015). Bu çalışma ise, reklam müziklerinin ikna üzerindeki etkisini müzikal unsurların organizasyonu üzerinden ele alması bakımında özgün bir nitelik taşımaktadır.

\section{Reklamlarda İkna Edici İletişim Süreci}

Reklam; insanları gönüllü olarak belli bir davranışta bulunmaya ikna etmek, belirli bir düşünceye yöneltmek, dikkatlerini bir ürüne, hizmete, fikir ve kuruluşa çekmeye çalışmak, onunla ilgili bilgi vermek, ona ilişkin görüş ve tutumlarını değiştirmelerini veya belirli bir görüşü ya da tutumu benimsemelerini sağlamak amacıyla oluşturulan; iletişim araçlarından yer ya da süre satın almak yoluyla sergilenen ya da başka biçimlerde çoğaltılıp dağıtılan ve bir ücret karşılığı oluşturulduğu belli olan duyuru (Gülsoy,1999,9) olarak tanımlanmaktadır. Reklamlar, tüketicilerin marka hakkında bilgi sahibi olabilmesi, markaya ait ürün ve hizmetlerin tanıtılabilmesi amacıyla stratejik olarak planlanan iletişim faaliyetleridir. Reklamların markayı tanıtmak kadar önemli bir diğer misyonu ise tüketiciyi satın almaya ikna etmektir (İplikçi, 2015, 66).

İkna edici olması, reklamların diğer iletişim türlerine göre en baskın özelliği olarak değerlendirilebilir (Babacan, 2015, 47). İkna, insanların seçimlerini onlar üzerinde baskı kurmadan etkilemeyi amaçlayan bir iletişim yönetimidir (Gerçik, 2015, 144). Bir diğer tanımda ikna, bilinçli ve planlı bir şekilde bireyleri etkileme çabasıdır (Madran, 2012, 15). Birçok bilim adamının birbirine yakın tanımlamalarına dayanarak iknayı kısaca, kaynağın hedefi belli bir konu ya da duruma ait olumlu tutum ve davranış oluşturma veya var olanı değiștirme amaçlı eylemler olarak tanımlamak mümkündür (Babacan, 2015, 47). İkna konusunda ilk çalışmaların Aristo tarafından yapıldı̆̆ı bilinmektedir. Aristo'ya göre, ikna gücü en yüksek mesajlar, "ethos", "patos" ve "logos" olmak üzere üç temel unsuru içermektedir. Ethos, konuşmacının kişisel özelliklerinin iknaya etkisiyle ilgilidir. Çekicilik (karizma) ve inanılırlık/ 
güvenilirlik ethos'un temel parçalarıdır. Pathos, konuşmacının dinleyici üzerinde yarattığı duygusal etkiyi anlatmaktadır. Duygusal bağların vurgulanması yoluyla ikna etmenin önemi üzerinde durmaktadır (Madran,2012,23). Logos ise, iknada yer alan insanların mantık yeterlilikleri, olay ve olgulara mantıklı bakışları ile ilgilidir (Yüksel, 2005, 23).

Darıcı $(2013,16)$ 'ya göre reklamcılar, etkili bir iletişim ve reklam ortamı yaratabilmek için tüketiciler üzerinde "ikna edici iletişim" uygulamalarını kullanmaktadır. Hedef kitlenin davranış ve tutumlarını zor kullanmadan değiștirmeyle ilişkili olan ikna edici iletişim sürecinin unsurları temel iletișim sürecinin unsurlarıyla aynıdır. Bir iletişimin sürecinde; kaynak (verici), mesaj (ileti), kanal (araç) ve hedef (alıcı) olmak üzere 4 temel unsur yer almaktadır. Bu dört temel unsur arasındaki ilişki ise; kod/ kodlama, kod açma/ yorumlama, geribildirim ve gürültü öğeleriyle sağlanmaktadır (Telman ve Ünsal, 2009, ss.28-34; Kaya, 2011, 7-11 ).

Kaynak, iletişim sürecini başlatan birimdir. İknada edici iletişim sürecinde alıcının tepkileri kaynağın özelliklerine göre değișmektedir. Kaynağın güvenilirliği iknayı etkileyen en temel unsurdur. Kaynağın sözleri ve beden dili arasındaki uyum, yine kaynağın dinleyicilere odaklanması, onlarla kurduğu göz teması mesajın etki düzeyini yükseltmektedir (Gerçik, 2015, 144). İkna sürecinin ikinci temel unsuru mesajdır. Mesaj olmadan bir iletişim sürecinden bahsetmek mümkün değildir. İkna edici mesajın motive edici güç yaratması ve bunun davranışa sebep olması gerekmektedir (Darıcı, 2013, 22). Mesajın özellikleri iletişim sürecinin ikna ediciliğinde önemlidir. Örneğin mesaj, kişilerin ihtiyaçlarına göre yapılandırıldığında ikna gücü artmaktadır. Eğer aktarılan mesaj kişinin ihtiyaç ve ilgileriyle örtüşmüyorsa kişi mesaja karşı olumlu veya olumsuz bir tepki geliştirmez. Kişinin harekete geçmesi için aktarılan mesajın kişinin ihtiyaçlarına cevap vermesi veya ihtiyaç konusunda bir farkındalık oluşturması gerekir (Gerçik, 2015, 150). Dolayısıyla etkili bir ikna sürecinde kaynak; alıcının ihtiyaçlarına, isteklerine, ilgi ve beklentilerine net cevap verdiği ya da hitap ettiği oranda alıcıyı kendine yakınlaştırabilir. Bunun için kaynak alıcının kodlarını bilmeli ve kendi iletisini ona göre kodlamalıdır. Başka bir anlatımla kaynağın sadece içerik ve amaç açısından değil aynı zamanda kod, kavram ve biçim olarak da hedefi ikna açısından tatmin etmesi gerekir. Kaynağın hedeflediği anlamın alıcının aklında oluşturulması için kodlanan anlam ile alıcının kodları birbirine uyumlu olmalıdır (Baban, 2005, 4). Kodlanan mesajların alınıcıya aktarıldığı ortam, kanal veya araç olarak tanımlanmaktadır. Bir iletişim sürecinde kanalın doğru şekilde kullanılması (örn. kanalın özellikleri, kapasitesi, hedef kitleye uygunluğu vs...) mesajın ikna ediciliği üzerinde belirleyici bir unsur olarak karşımıza çıkmaktadır. Kanal üzerinden alıcıya ulaşan mesajların çözümlenmesi başka bir ifadeyle alıcı tarafından anlamlandırılması ise kod açma olarak adlandırılmaktadır. Alıcı, kaynağın gönderdiği iletilerin hedefidir. Başka bir anlatımla mesajı algılaması istenen kimsedir. Alıcıda iknanın gerçekleşmesinde yaş, cinsiyet, ırk ya da eğitim gibi demografik faktörler etkili olabildiği gibi verilen mesaja yanıt süresi, tepki gösterme eğilimi, bilişsel denge, farklı kişilik yapıları ve sosyal baskı gibi psikolojik yapıya bağlı etkenlerde etkili olabilmektedir (Darıcı, 2013, 23). Gürültü iletişim sürecinde yer alan ve gönderilen ileti ile alınan ileti arasında herhangi bir fark yaratan ögedir. Gürültü ikna edici iletişim sürecini olumsuz olarak etkilen tüm unsurlardır. Dolayısıyla ikna edici iletişim sürecinde kaynağın amaca ulaşması ve mesajın hedef kitle üzerindeki etkinliğinin artırılmasında gürültünün en az indirilmesi gerekmektedir. Gürültünün 
en aza indirilmesi belli bir oranda iletişimde kullanılan kanala ve iletinin iyi ve gereklerine uygun biçimde kodlanıp kullanılmasına bağlıdır (Yüksel, 2012,12). Hedef kitlenin gönderilen mesaja verdiği tepki geribildirim olarak adlandırılmaktadır. İkna edici iletişim sürecinde geribildirim, mesajın amacına ulaşıp ulaşmadığını analiz etmemize ve elde ettiğimiz veriler doğrultusunda mesajı yeniden düzenlememize olanak tanımaktadır.

İkna edici iletişim sürecinin istenilen yönde sonuçlanması için bütün bu unsurların birbiriyle uyumlu olması ve birini desteklemesi gerekmektedir. Çünkü ikna sürecindeki bu dört temel üç ara öğenin özellikleri hem birbirini etkilemektedir hem de ikna edici iletişim sürecinin başarısını belirlemektedir.

Çoğu durumda, ikna edici mesajların nihai hedefi, bir aday için oy sağlamak, emniyet kemerlerinin takılmasını sağlamak, bir amaç için bağış toplamak ya da bir ürünün satın alınmasını sağlamak gibi amaçlanan bir davranışı üretmektir. Sosyal psikologlar ve medya uzmanları, mesaj, mesajın kaynağı (örn. konuşmacı) ve alıcı gibi girdi değişkenlerinin her birinin, mesaja maruz kalma, dikkat, kavrama, yeni bir tavır kazandırma ve tavra dayalı eylemi içeren psikolojik süreçlerin (çıktı değişkenlerinin) müzikal öğelerinin hiyerarşik olarak düzenlenmesi yoluyla iknaya nasıl etki edebileceğini düşünmüşlerdir (Shevy ve Hung, 2013, 312).

\section{İkna Edici İletişimde Reklam-Müzik İlişkisi}

Müzik, duygu, düşünce, tasarım ve izlenimleri, belli bir amaç ve yöntemle, belirli bir güzellik anlayışına göre birleștirilmiş seslerle işleyip anlatan estetik bir bütündür (Angl, 2013, 61). Müziğin kökeni hakkında çeşitli fikirler ortaya atılmıştır. Bir kısım araştırmacı şarkı söylemenin hayvan seslerini taklit ile başladığını bir kısım araştırmacı ise şarkının kökeninin ses tonunun yükseltilmesi ile oluştuğunu ileri sürmektedir. Diğer araştırmacılar ise müziğin çıkış noktasının konuşma ile aynı olduğu ve her ikisinin de ses iletişimiyle başladığı konusunda birleşmektedir (Özulu, 1994, 61).

Müziğin kökeni hakkında farklı görüşler yer almakla birlikte hepsinin ortak noktası bilgi, duygu ve düşüncelerin aktarımında müziğin etkili bir araç olduğudur. Dolayısıyla günlük hayatımızın her anında karşımıza çıkabilen müziğin kullanım alanı çok zengin ve geniştir (İmik, 2016, 12). Müziğin yakın ilişki içerisinde olduğu alanlardan birisi de reklamcılıktır. Reklamcılık alanında müziğin kullanılmasının ilk olarak sokak satıcılarının mallarını tanıtırken yüksek sesle söyledikleri melodiler ile başladığı kabul edilmektedir. Günümüzde ise müzik reklamcılık sektörünün vazgeçilmez bir aracı haline gelmiştir. Reklamların istenilen amaca erişmesinde en büyük yardımcı etken müzik olarak görülmektedir (Özulu, 1994, 61). Reklamlarda müzik markalandırmaya önemli katkılarda bulunurken marka ve tüketici arasında da duygusal bir bağ oluşturmaktadır. Örneğin Avustralyalı ulusal havayolu şirketi Quantas bir çocuk korosunun söylediği “Ben Avustralya’ya Hala Yuvam Diyorum (I Still Call Australia Home)" adında özel bir derleme çlkarmıştır: Bu parça bütün Quantas uçaklarının kalkış ve inişi sırasında çalınmaktadır. Bütün televizyon ve radyo reklamlarında mutlaka yer alan bu melodi havayolu ile tüketici arasında duygusal bir yaratmada son derece başarılı olmuştur (Lindstrom, 2007, 66).

Reklamlarda müzik, "fon müziği” ve “cıngıl” olmak üzere iki şekilde kullanılarak reklamın etkinliğini desteklemektedir. Fon müzikleri, reklamın mesajını taşıyan 
sözlerin altına döşenen ve reklamda sözler gibi belli etkileri yaratmak için kullanılan müzik parçalarıdır. Fon müziklerinin beklenen amaca hizmet edebilmesi için, reklamın tarzına, ürünün niteliğine ve kurulan dramatik çatıya uygun olması gerekmektedir. Fon müziğinin seçiminde dikkat edilmesi gereken en önemli nokta sözlerden daha baskın durumda olmamasıdır. Aksi halde reklamın etkisini azaltabilir, dikkati dağıtabilir, dolayısıyla reklam mesajının dinleyiciye yeterince ulaşmasını engelleyebilir (Topsümer ve Elden, 2015, 130). Reklamın sözel (veya görsel) içeriğinin çok önemli olduğu durumlarda örneğin, yasalarca faydası ve yan etkisi hakkındaki bilgilerin belirtilmesi gereken aspirin gibi ilaçların (her ne kadar ülkemizde tıbbi ilaç ve malzemelerin reklamları yasak olsa da konunun önemi bakımından belirtilmiştir) reklamlarında arka plan müziğinin bu türü yaygın olarak kullanılır. Buna ek olarak, reklamcılar, bir ünlünün reklamda gözükmesi gibi belirli bir konuya odaklanmış seyircinin dikkatini çekmek istediklerinde de bu tür müzikleri kullanırlar (Hoeberichts, 2012, 11).

Reklamlarda ürünün temel yararları ise genelde cıngıl adı verilen reklam müziği ile anlatılmaktadır. Reklama konu olan ürünün vurgulanmak istenilen özelliklerinin anlatıldığı cıngıllar, mesajın akılda kalmasını kolaylaştırmanın yanı sıra dikkat de çekmektedir (Tosun, 2003, 161). Genellikle hareketli ve ritmik müzik parçalarından oluşan cıngıllar bazen reklamın tümü olabilir. Böyle durumlarda cıngılın sözleri reklam metninin yerini alabilmektedir (Topsümer ve Elden, 2015, 129). Cingll formundaki reklam müziğini seslendiren de ayrıca önem taşımaktadır. Ünlü şarkıcıların seslerinin reklamlarda yer alması markanın reklamlarına olan ilgiyi artırmaktadır. Ancak dış ses gibi, müzik eserini seslendiren kişinin ses renginden, tonuna kadar, diksiyonundan sarkıcının kendi müzikal karakterine kadar pek çok nokta markanın algılanması açısından etkili olmaktadır (Akgün, 2007, 48). Cıngılların reklam aracı olarak kullanımının, ticari radyoların gelişimiyle paralellik gösterdiği görülmektedir.

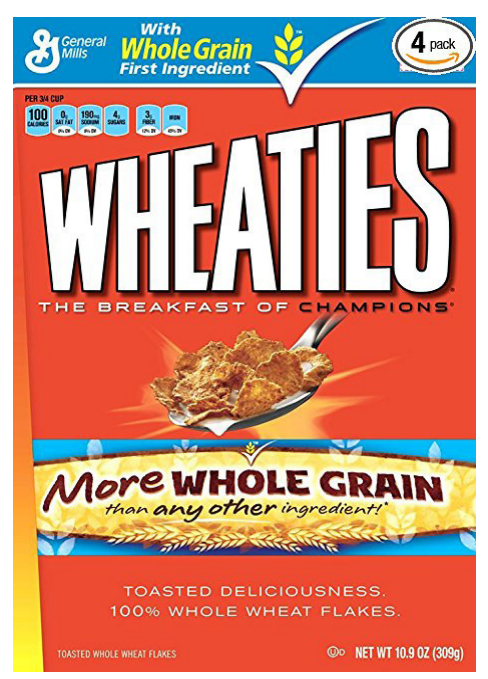

Fotoğraf 1: https://www.amazon.com/Wheaties-Cereal-10-9-Box-pack/dp/B003VZF2X6

1926 Noel arifesinde General Mills gıda şirketine ait Wheaties tahıl gevreğiyle ilgili kısa bir şarkının Wheaties Quartet adlı bir müzik grubu tarafından akapella türünde seslendirilmesi ilk radyo cıngılı yayını olarak bilinmektedir. Tahıl gevreği üretimini bırakmayı düşünen şirket yöneticileri, cıngılın yayınlandığı bölgelerde satışların ve markanın bilinirliğinin belirgin bir şekilde artığını belirmişlerdir (Austin, 2014, 155). 
Türkiye'de ise reklamlarda müziğin ikna aracı olarak kullanımı 1960’lı yıllara dayanmakla birlikte sektörün asıl 1980'li yılların sonunda gelișme gösterdiği görülmektedir. Eti'nin “Bisküvi denince akla hemen onun adı gelir", Ülker'in "Akșama babacığım unutma Ülker getir" ve Billur Tuz'un "Akar, akar, akar" reklam müzikleri ilk akla gelen örneklerdir. 2001 yılında gerçekleștirilen ve Avrupa Basketbol Şampiyonası'nda basketbol milli takım sponsorluğuna ilişkin Garanti Bankası için oluşturulmuş “12 Dev Adam” kampanyasını, Türk reklamcılığında müzik kullanımı için bir mihenk taşı olarak değerlendirmek mümkündür (Batı, 2010, 13).

Reklamlarda müzikli anlatım yolu; hedef kitlede olumlu duyguların uyandırılmasına, çekilen dikkatin sürekliliğinin sağlanmasına vehatırlanmanın kolaylaşmasına katkıda bulunmaktadır (Tosun, 2003, 161). Bu yolla reklam mesajının etkinliğinin artırılması hedeflenmektedir. Ancak kullanılan müziğin ürünün/hizmetin özellikleriyle, hedef kitlenin nitelikleriyle, reklamda hedeflenen temel satış vaadi, verilmek istenilen mesajla ve kullanılan uyarıcıların türüyle uygun olması gerekir. En önemlisi de reklamın ve reklamı yapılan markanın önüne geçmeyecek, markanın hatırlanmasını destekleyecek bir özellik taşımasıdır (Elden vd., 2015). Başka bir anlatımla reklam metninin hazırlanmasında tanıtımı yapılacak ürünün, potansiyel tüketici kitlesini ikna ederken, hedef kitleye ve özellikle de reklam metninin içeriğine uygun düşecek bir müziksel metin kullanmak ya da tasarımlamak önemli bir unsurdur (Genç, 2012 48). Müzik birçok yolla reklam hedeflerinin gerçekleşmesine hizmet edebilir. Huron $(1989,560)$ müziğin etkili bir reklama katkıda bulunabileceği altı temel yol tanımlamıştır. Bunlar:

1. Eğlence: İyi müzik, sadece daha çekici hale getirerek bir reklamın etkililiğine katkıda bulunabilir. Hedef kitlenin dikkatini çekebilmenin en basit yolu eğlencedir. İngilizcesi "entertain" olan "eğlendirmek" sözcüğü etimolojik olarak "dikkat çekme" ya da "ilgi uyandırma" anlamına gelmektedir.

2. Yapı/devamlılık: Müzik çeşitli yapısal roller de oynamaktadır. Müziğin en önemli yapısal rolü, bir dizi görsel imgeyle teatral olayları, öyküleyici dış sesleri veya ürün çekiciliklerini birbirine bağlamasıdır. $\mathrm{Bu}$, müzikte devamlılığın bir fonksiyonudur.

3. Hatırlanabilirlik/Akılda kalıcılık: Reklamlarda müzik, bir ürünü veya bir ürünün adının hatırlanabilirliğini artırmaktadır. Tüketicilerin, sadece ürünün ismi bile olsa bir şekilde aşina oldukları ürünleri tercih ettikleri bilinmektedir. Müziğin akılda kalıcılığı insanın işitsel ve bilişsel özelliklerinden birisidir.

4. Lirik dil: Müzik, sözlü bir mesajın sözsüz bir şekilde aktarılmasına olanak sağlamaktadır. Basitçe konuşmak yerine müzikal bir şekilde konuşulduğunda söylenen şeyler kulağa daha az sıradan ve tesadüfi gelmektedir. Konuşma ve şarkının karışımı reklamcılar mantıksal-gerçekçi çekiciliklerle duygusal-şiirsel çekiciliklere aynı anda hitap etme firsatını sunmaktadır.

5. Hedefleme: Reklam mesajlarının belirli bir kitleye odaklanmasına "hedefleme" denilmektedir. En uygun hedefleme stratejisi, geniş pazar segmentine erişimi artıran dengeli medya maliyeti stratejisidir. Birden çok medya aracının eş zamanlı olarak kullanıldığı karma bir stratejidir. Uygun medya belirlendikten sonra hedeflemenin ikinci amacı, hedef demografik grubu oluşturan kitlelerin dikkatini çekebilmektir. Müzik tarzlarının çeşitli sosyal ve demografik grupları tanımladığı bilinmektedir. Dolayısıyla müzikal tarz, belirli bir pazarı hedeflemeye yardımcı olabilir. 
6. Yetkinlik oluşturma: Yetkinlik oluşturma bir reklamın güvenilirliğin artırmada önemli bir unsurdur. "Diş Hassasiyetine Karşı Uzmanlar Sensodyne'i Öneriyor" (https://www.youtube.com/watch?v=OvMXtvw-nDE) reklaminda görülebileceği gibi bir uzman beyanı veya Balparmak ambalajlarında yer alan kare kodu (QR kod) akıllı telefonlarına okutan tüketicilerin satın aldıkları balın Türk Gıda Kodeksi'ne uygun olduğunu gösteren analiz raporuna ulaşabilmeleri (Balparmak'tan E-Bülten, 2017) örneğinde görülebileceği gibi bir uzman onayı, yetkinlik oluşturmanın en basit yoludur.

Bu katkıların her biri, müziği markanın genel imajına ekleyerek ürün ile müşteri arasındaki bağlantıyı daha güçlü yapıp, reklamcıların hedef kitleleriyle duygusal bir düzeyde bağlantı kurmasında ve tüketicilerin reklamda duydukları müzikle reklamı yapılan ürün arasında bağlantı kurmak için tüketicinin yönlendirilmesinde reklamcılara yardım etmektedir (Austin, 2014, 155). Müziğin reklamlarda kullanılmasının en temel sebeplerinden birisi reklamın beğenilmesine katkı sağlamasıdır. Müzik, reklamı izleyenlerde mesajı verirken duygulara hitap ederek, akılda kalıcılığı hedeflemektedir. Reklamı izlerken eğlenen izleyici için neşeli duyguların canlandırılması, istenilen dramatik etkinin oluşturulması ve markaya bu olumlu duyguların yansıtılması için müzik kullanılmaktadır (Uğur, 2011, 16). Bu konuda yapılan araștırmalar, müziğin duyguların oluşumu üzerindeki etkisinin çeşitli unsurlar tarafından belirlendiğini ortaya koymaktadır. Ritim, tempo, ölçü, kalıp, sesin perdesi ve sesin şiddeti araştırmaların çoğunda ele alınıp analiz edilen baskın unsurlardır.

Ritim: Her notadan belli bir usul içerisinde uzun ya da kısa oluşu o notanın ritmini belirler. Ritim olgusu evrende kalbin çarpması, yıldızların hareketi, gün ve mevsimlerin dönüşü gibi pek çok olayda, müzikten çok daha öncelerinden, mevcuttur. Müzikte basit ya da bileşik ritimlerle ifade edilir. 4/4, 3/4, 2/4 gibi ritimler basit, 6/8, 9/8 gibi ritimler bileşik ritimlerdir (Kutlay, 2007, 11). Ritmik denildiğinde; müzik eseri süresince karşımıza çıkan bir ya da daha çok sayıda sabit ritimlerden (tango, vals vb.); serbest ritmik denildiğinde ise, icra edenin hissedişi ve estetik anlayışı çerçevesinde şekillenen ve fakat tango, vals vb. isimler ile sabitlenmemiş, adı konmamış, zaman içinde o eserle özdeşleșmiş bir 'iç ritm'den söz edilmektedir. Örneğin Türk Halk Musikisi'nde 'Kırık Hava'lar ritmik, 'Uzun Hava'lar serbest ritmik olarak tanımlanabilir. Tek bir eserin içinde; hem ritmik, hem serbest ritmik bölümler de bulunabilir (Özeren, kişisel görüşme, Şubat 2018). Düzenli / basit ritim mutluluk, haysiyet, görkem ve barışseverliği ifade eder şekilde algılanabilir; düzensiz / bileşik ritim, eğlence, huzursuzluk ve öfkeyi ifade edebilir; değişken ritim ise sevinci ifade edebilir. Sabit ritim üzüntü, asalet ve canlılık ifadeleriyle, akan/akıcı ritim ise mutlu / neşeli, zarif, dinlendirici ve huzurlu gibi ifadelerle ilişkili olabilir (Gabrielsson ve Lindström, 2011, 391).

Tempo: Bir müziğin kendi karakterine uygun olarak hızlı, orta ya da yavaş hareketli oluşu o müziğin temposunu ifade eder. Vuruş sayısı/ dakika birimiyle ölçülür. Müziğin temposu Latince terimlerle ifade edilir. Yavaştan hızlıya tempo terimleri; Largo (çok yavaş), Adagio (yavaş), Andante (yavaşça), Moderato (orta hızda), Allegrretto (hızlıca), Allegro (hızlı) ve Presto (çok hızlı)'dur (Kutlay, 2007, 11). Tempo ne kadar hızlı olursa canlılık ve mutluluk o kadar çok ifade edilmektedir. Hızlı müzik yavaştan daha neșelidir ve tercih edilen tempo birimi dakikada 70 ile 110 vuruştur (Bruner, 1990, 95). Hızlı tempo, çeşitli aktivite / heyecan, mutluluk / 
sevinç / hoşluk, güç, sürpriz, rahatlık / tuhaflık, öfke, huzursuzluk ve korku ifadeleri ile ilişsilendirilebilirken, yavaș tempo, sakinlik / dinginlik, barış, hüzün, asalet / ihtişam, hassasiyet, özlem, can sıkıntısı ve iğrenme ifadeleriyle ilişkilendirilebilir. Hem hızlı hem de yavaş tempo ise diğer yapısal faktörlerin varlığı ve seviyesine bağlı olarak birçok farklı ifade ile ilişkilendirilebilir (Gabrielsson, 2008, 2018).

Müziğinölçüsü: Bir müzik eserinin süre olarak birbirine eşit parçacıklarabölünmesine ölçü denir. Daha basit bir ifadeyle ölçü eşit zaman kümeleridir (MEB, 2011, 36). Zamanın ölçümü vuruşlarla yapılır. Vuruşlar iki, üç veya dört vuruş şeklinde gruplanırlar ve dolayısıyla bir ölçüde iki vuruş (iki zamanlı), bir ölçüde üç vuruş (üç zamanlı) ve bir ölçüde dört vuruş (dört zamanlı) gibi oluşumlar ortaya çıkar. İki zamanlı, üç zamanlı ve dört zamanlı ölçüler iki ana grupta toplanırlar: 1-Basit ölçüler: Bir zamanın iki ve katlarına bölündüğü ölçüler, 2-Bileşik ölçüler: Bir zamanın üç ve katlarına bölündügü ölçüler (Çelebioğlu, 2008, 26). İkili ve dörtlü ölçüler üçlü ölçülerden daha yavaştır. Bu yüzden Descartes (Aktaran: Dissmore, 2017, 13), üçlü ölçüleri "daha hızlı" ve "daha yüksek" duygularla ilişkilendirmektedir. Çünkü içerisinde dikkat edilmesi gereken daha çok şey içerdiklerinden dolayı duyuları daha fazla meşgul etmektedir. Öte yandan Descartes ikili ölçülerin basit ifadelerden oluştuğu için "daha basit" duygular uyandırdığına inanmaktadır.

Müziğin kalıbı: Hevner (1937), müzikte majör ve minör kalıpların duygusal karakteri üzerine yaptığı çalışmada, majör ve minör kalıpların duygusal özelliklerinde farklılıklar olduğu geleneksel varsayımını ampirik olarak değerlendirmeyi denemiştir. Hevner bu çalışmasında majör kalıpların dinamik güç, sevinç ve heyecan ifadeleriyle ilişkilendirilmiş olduğunu ve umut, güç ve mutluluk çağrışımları olduğunu belirtmiştir. Minör kalıpların ise geleneksel olarak pasif, ağır ve muhtemelen keder, üzüntü, gizem ve sakinlik hissini ifade ettiği kabul edilir. Benzer bir çalışma Dalla Bella vd., tarafından gerçekleştirilmiştir. Dalla Bella vd., (2001, 2)'e göre, mutluluk ve üzüntü temel duygulardır ve müziksel olarak ifade edilen en güvenilir ve ayırt edilebilen duygulardır. Ayrıca mutlu/üzgün ayrımının majör yapısal belirleyicileri tempo ve kalıp olarak iyi bir şekilde tanımlanmıştır. Hızlı tempo mutlu bir ton çağrışımı yaparken, yavaş tempo üzgün bir ton çağrışımı yapmaktadır. Benzer şekilde, majör mod mutlulukla, minör mod ise üzüntü ile ilişkilendirilmektedir.

Sesin Perdesi: Bir müzik eserini meydana getiren seslerden her birinin kalınlık veya incelik derecesi, sesin tizliği veya pesliğine perde denmektedir. Her perde bir eşik işlevi görmektedir ve müzik aletinin telinin titreşen uzunluğunu belirlemektedir (Baydu, 2016, 316). Titreşimler ne kadar sıksa ses o kadar tiz, ne kadar seyrekse ses o kadar pes tınlamaktadır (Kutlay, 2007, 12). Araștırmalara göre perdenin yükselmesi ve alçalması çeşitli duygusal etkiler yaratmaktadır.

Jaquet vd. (2012, 54)'nin konuyla ilgili gerçekleştirilen çalışmaları (Collier ve Hubbard, 2001; Coutinho ve Cangelosi, 2009; Eitan ve Timmers, 2010; Gundlach, 1935; Hevner, 1937; Kleinen, 1968; Rigg, 1940; Watson, 1942; Wedin, 1972) inceleyerek yaptıkları değerlendirmeye göre bazı çalışmalar, yüksek perdeli (tiz) müziğin, mutlu, zarif, rüya gibi, hoş ve hafif gibi olumlu duygusal sıfatlarla daha çok ilişkili olduğunu gösterirken, alçak perdeli (pes) müziğin daha çok üzgün, dramatik, karanlık, ajite edilmiş, sıkılmış ve kasvetli gibi olumsuz duygusal sıfatlarla ilişkili olduğunu göstermektedir. Diğer taraftan, tiz ses öfke ve korku gibi olumsuz duygular ile ilişkilendirilirken, pes ses hoşluk ile ilişkilendirilmektedir. Ses perdesi ile 
uyarılma arasındaki olası ilişkiye ait bulgular oldukça çelişkilidir. Tiz müzik, heyecan, coşkunluk, hayat doluluk, hareketlilik, canlılık, güç gibi yüksek uyarıcılık terimleri ve öfke ve korku gibi yüksek uyarıcı duygularla ilişkilidir (Jaquet vd., 2012, 54). Ses perdesi ses tasarımında iyi bilinen bir faktördür. Örneğin, uyarı durumlarında kullanılmak üzere yüksek aciliyet sesi tasarlarken, insan algısı perdeden büyük ölçüde etkilenir. Tiz ses kendisine karşılık gelen pes sesten daha fazla aciliyet taşır (Hagman, 2010, 11).

Sesin Şiddeti: Şiddet fizyolojik olarak bir sesin ortaya koyduğu kuvvet duygusudur. Forte ve Piano sesin şiddetine ilişkin en yaygın kullanılan kavramlardır. Forte, icrada ses şiddetinin yüksek olması gerektiğini belirten nüans terimidir. Piano ses şiddetinin azaltılması gerektiğini belirten yorum terimidir (Baydu, 2016, 146, 397). Sesin yüksekliği, duygusal tepkileri önemli ölçüde etkileyen başka bir faktördür. Yüksek sesli müzik, yoğunluk / güç, heyecan, gerginlik, öfke ve sevinç gibi çeşitli ifadeleri ile ilişkilendirilebilirken, düşük sesli müzik- hafif müzik yumuşaklık, huzur, hassasiyet, üzüntü, kibarlık ve korku ile ilişkilendirilebilir. Genel olarak, yüksek sesli müzik, yüksek aktivasyon ve güç ile ilişkili görünmekte iken, düşük sesli müzik hafif müzik düşük aktivasyonlu ve belki de aktivasyon itaatkârlığı ile ilişkili gibi görünmektedir. Yoğunluktaki hızlı değişimler, oynaklık, yalvarma ya da korku, çok az değişiklikler ya da değişiklik olmaması üzüntü, barış ve asaletle ilişskili olarak görünebilir (Gabrielsson ve Lindström, 2011, 389).

Bruner (1990, 95)'ın farklı çalışmalardan yola çıkarak derlediği, belirli müziksel özelliklerin taşıdığı duygusal anlamlara ilişkin veriler aşağıdaki tabloda şu şekilde yer almaktadır:

Tablo 1: Çeșitli Müzik Bileșenlerine Atfedilen Duygusal İfadeler

\section{Zaman Bağlantılı İfadeler}

1. İkili ritimler, daha serbest ve coşkun olan üçlü ritimlerle karşılaştırıldığında, katı ve kontrollü bir ifade üretmektedir.

2. Tempo ne kadar hızı olursa canlılık ve mutluluk o kadar çok ifade edilmektedir.

3. Ritmik hareketler bazı duyguların engelsiz akışını temsil edebilirken; serbest ritmik ve aksak ritimler daha karmaşık ifadeler üretmektedir.

4. Yumuşak bir akışı olan ritimler daha eğlenceli bir duygu uyandırırken sert bir akışı olan ritimler daha ciddi bir ruh halini ifade etmektedir.

5. Kesik (Staccato) notalar bir parçaya, bağı (legato) notalardan daha fazla vurgu yapmaktadır.

\section{Perde Bağlantılı ifadeler}

1. İnişli çıkışlı ses perdesi, sadece fiziksel anlamda iniş çıkışlara karşılık gelmez aynı zamanda hem "dışında ve içinde olmak" la hem de "gitmek ve geri dönmek" le de örtüşür.

2. Yükselen ve düşen ses perdeleri belirli bir duygusal bağlamda büyüyen veya azalan yoğunluğu ifade edebilir.

3. Yüksek anahtarlı ${ }^{1}$ şarkıların (sol anahtarı gibi) düşük anahtarlı şarkılardan (fa anahtarı gibi) genellikle daha mutluluk verici olduğu düşünülür.

4. Majör kalıplardan (8 ses ve 2 tam 1 yarım 3 tam 1 yarım aralıklarından oluşan dizin) oluşan şarkılar, minör kalıplardan (1 tam 1 yarım 2 tam 1 yarım 2 tam aralıklarından oluşan dizi) oluşan şarkılardan daha hareketli olup, daha fazla olumlu duygular ifade eder.

5. Kompleks armoniler ${ }^{2}$, sakin ve mutlu olan basit armonilerden daha ajite edici (sarsıcı, huzursuz edici) ve üzücüdür.

\section{Yapı Bağlantılı İfadeler}

1. Yüksek ses, canlılık ve yakınlığı ifade ederken, düşük ses sakinliği ve uzaklığı ifade eder.

2. Crescendo (sesin şiddetinin giderek artması) güç artışını ifade ederken, diminuendo (sesin şiddetinin giderek hafiflemesi) güç azalışını ifade eder.

3. Trompet, trombon gibi pirinçten yapılma nefesli müzik aletlerinin tınıları soğuk ve sert bir duygu yaratırken, flüt, klarnet gibi kamışlı müzik aletleri yalnızlık ve melankoli hissi yaratır.

Kaynak: Bruner, 1990, 95. 
Kısaca reklam müziklerinin nihai amacı, duygulara hitap etme yoluyla tüketicilerde beğeni oluşturarak onları satın alma davranıșına ikna etmek ve reklamda gösterilen ürün veya hizmetin satışını arttırmaktır. Bu amaç doğrultusunda reklam müzikleri iki farklı yolla oluşturulmaktadır. Bunlardan birincisi yeni bir reklam müziği fikri ve melodisi geliştirmektir. Bu yeni fikir, reklamı düşünülen metanın istenilen özellikleri göz önünde bulundurularak tasarımlanmaktadır. Böylelikle özgün bir reklam müziği yapıtı ortaya konulmuş olacaktır. İkinci seçenek hali hazırda var olan, daha önceden bestelenmiş ve genellikle halk arasında yaygın olarak bilinen bir eserin farklı şekillerde (ritmik, armonik vs.) düzenlenerek tekrar gündeme getirilmesidir (İmik, 2016, 67). Reklamcılar, popüler müziği potansiyel tüketiciyi olaya dahil etmek, bağlamak ve nihayetinde ürün veya hizmetlerini satın almak için ikna etmek adına çeşitli șekillerde kullanırlar. Allan $(2006,442)$ tarafından yürütülen çalışmanın sonuçları, popüler müziğin bazı bireyler için kişisel olarak anlamlı olabileceğini ve reklamlarda kullanıldığında dikkat ve hafızayı etkileyebileceğini açıkça göstermektedir.

Kellaris ve ark. $(1993,123)$ reklamcılıkta müzik kullanımıyla ilgili yapmış oldukları çalışmanın sonucunda iki öneri sunmaktadır. İlk olarak, bulgular, reklamcılar müzik kullanırken, kendi iletişim amaçlarıyla ilgilisini dikkate almaları gerektiğini göstermektedir. Marka bilinirliği ve marka bilgisinin öncelikli hedef olduğu durumlarda, tüketicinin mesaj ve marka adını almasını engelleyebilecek müzikten kaçınmak için müziğin tasarımı veya seçimi son derece dikkatlice olmalıdır. İkincisi, eğer bir reklamcı müzik kullanırsa, bu müzik dikkati üretme yeteneği ve müzik ve mesajla oluşturulmuş düşünceler, imajlar ve duygular arasındaki uyum yeteneği için bir ön testten geçirilmelidir. Şimdilik, elde edilen sonuçlar diğer kategorilere nazaran, son derece dikkat çekici, ahengi yüksek olan müziğin seçilmesi gerektiğini önermektedir.

\section{Banka Reklam Müziklerinin İkna Stratejileri Açısından İncelenmesi Üzerine Nitel Bir Çalışma}

Reklamlar; görsel, işitsel ya da görsel ve işitsel öğelerin bir arada kullanılmasından meydana gelmektedir. Reklam ilk bakıșta büyük oranda görsel bir öğe olarak düşünülse de görüntü üzerine ses öğelerinin eklenmesiyle hem etkinliği hem de ulaşılabilirliği artırılabilmektedir (İmik, 2016, 66). Günümüzde reklam müzikleri, hedef kitleleri etkilemek ve onları belirli davranışlara ikna edebilmek için kullanılan en önemli unsurlardan birisi olarak karşımıza çıkmaktadır.

\section{Araştırmanın Amacı}

$\mathrm{Bu}$ çalışmanın amacı; Türkiye'nin marka değeri en yüksek bankalarının son yayınlanan televizyon reklam filmlerinde mesajın etkinliğini artırmak için kullandıkları müziklerin ikna edici iletişim açısından bir analizini ortaya koymak ve reklamlarda müziğin kullanımına ilişkin stratejilerin ikna stratejileriyle örtüşüp örtüşmediğini belirlemektir. Bu amaç doğrultusunda araştırmanın sorusu aşağıda yer aldığı şekilde belirlenmiştir:

"Banka reklam müziklerinde ikna edici iletişim stratejilerinden yararlanılmakta midır?" 


\section{Araştırmanın Yöntemi}

Bağımsız marka değerleme ve strateji danışmanlık şirketi Brand Finance'ın, “Dünyanın En Değerli 500 Banka Markası - 2017” araştırmasının sonuçlarına göre, Türkiye'den 9 banka listede yer almaktadır. Bu bankalar sırasıyla; Akbank, Garanti Bankası, Ziraat Bankası, İş Bankası, Yapı Kredi Bankası, HalkBank, VakıfBank, DenizBank ve Türkiye Ekonomi Bankası (TEB)'dir (http://brandfinance.com, 2017). Dünyanın En Değerli 500 Banka Markası - 2017 Türkiye listesinde yer alan bankalar bu araștırmanın örneklemini temsil etmektedir. 30 Ocak 2018 tarihi itibarıla araştırmanın örneklemini oluşturan bu bankaların yayında olan son televizyon reklam filmleri içerik analizine tabi tutulmuştur. Dolayısıyla bu çalışmada nitel bir araştırma yönetimi kullanılmıştır. Nitel araştırma genel olarak gözlem, görüşme ve doküman analizi gibi nitel veri toplama tekniklerinin kullanıldığı, algıların ve olayların doğal ortamda gerçekçi ve bütüncül bir biçimde ortaya konmasına yönelik nitel bir sürecin izlendiği araştırma olarak tanımlanmaktadır (Yıldırım ve Şimşek, 2011, 72). Birçok farklı türde nitel araştırma vardır. Örneğin; etnografya, gömülü teori, yorumlayıcı fenomenolojik analiz, söylem analizi, konuşma analizi, içerik analizi, anlatı analizi vd... (Hancock, Ockleford ve Windridge, 2009, 14). Bunların arasında özellikle dokümanları analiz ederken en uygun yöntemlerden biri olan içerik analizi (Hancock, Ockleford ve Windridge, 2009, 14), bir mesajın belli özelliklerinin objektif ve sistematik bir şekilde tanınmasına yönelik çıkarımların yapıldığı bir tekniktir. İçerik analizi metin veya metinlerden oluşan bir kümenin içindeki belli kelimelerin veya kavramaların varlığını, anlamlarını ve ilişkilerini belirleyerek ve analiz ederek metinlerdeki mesaja ilişkin çıkarımlarda bulunmaya yönelik yapılmaktadır (Büyüköztürk vd., 2008, 253).

Bu çalışmada içerik analizine tabi tutulan reklam filmlerine bankaların kendi web sitelerinden veya YouTube kanalından ulaşılmıștır. Türkiye'nin en değerli bankaları ve 30 Ocak 2018 itibarıyla yayında olan son reklam filmleri şunlardır;

1. Akbank T.A.Ș. - "Telefonu salla, kredini gör anında”

2. Garanti Bankası - "Herşey bir hayalle başlar"

3. Ziraat Bankası - "Senden vazgeçemem ben"

4. İş Bankası - "İş bankası 93 yaşında"

5. Yapı Kredi - "Dünyanın en yenilikçi dijital bankası Yapı Kredi!”

6. Halk Bank - "Halk adını taşımak"

7. VakıfBank - "Yanındaki güç"

8. DenizBank - "Denize çek gönder"

9. Türkiye Ekonomi Bankası-TEB - "Marifetli hesap"

Önceki bölümlerde yapılan literatür araștırması doğrultusunda reklamların müzik yoluyla ikna edici iletişim açısından öne çıkan olumlu duyguların oluşmasını etkileyecek unsurlar belirlenerek 10 temel kategori altında ele alınmıştır. Bunlar; müziğin türü, müzik parçasının ya da seslendiren kişinin ünlü olması, temposu, ölçüsü, ritim yapısı, nota anahtarı, tonu, armonisi, müziğin perdesi ve sesin şiddetidir. Çözümleme yapılırken Alp Özeren (Kişisel Görüşme, Şubat 2016) ve Fahrettin Özdeş (Kişisel Görüşme, Şubat 2016) olmak üzere 2 ayrı uzman görüşüne başvurulmuştur. Çözümleme sonucunda elde edilen veriler ikna edici iletişim açısından analiz edilmiş ve reklamlarda müziğin kullanımına ilişkin stratejilerin ikna stratejileriyle örtüşüp örtüşmediği belirlenmeye çalışılmıştır. 


\section{Bulgular}

Araștırma kapsamında ele alınan banka reklam müziklerinin genel çözümlemesine ilişkin bulgular aşağıda yer aldığı şekildedir:

Akbank T.A.SS. - "Telefonu salla, kredini gör anında": Reklam filminin süresi 43 saniyedir. Reklam müziğinin cıngıl ağırlıklı kullanımı söz konusudur. Müzik grubu Athena'nın "Ah Yaşamak Var Ya" şarkısı, sözleri kuruma uygun olacak şekilde yeniden yorumlanarak Akapella (Acapella) şeklinde okunmuştur. Reklamın sloganı cingll olarak verilmektedir. Basit bir armonisi olan müziğin tonu Fa Minor'dür. Sol anahtarının kullanıldı reklam müziği 4/4'lük basit dörtlü bir ölçüye ve ritmik bir yapıya sahiptir. Müziğin temposu çabuk yani Allegro (124-125 bmp)'dur. Akışın sert olduğu ikili bir ritim kullanılmıştır.

Garanti Bankası - "Herşey bir hayalle başlar": Reklam filminin süresi 1 dk. 25 saniyedir. Reklam müziğinin cıngıl ağırlıklı kullanımı söz konusudur. Bestesi ve sözleri Nil Karaibrahimgil'e ait olan "Yalnız Değilsiniz" șarkısını, Nil Karaibrahimgil ve Mehmet Erdem birlikte seslendirmektedir. Reklamın sloganı cıngıl olarak verilmektedir. Basit bir armonisi olan müziğin tonu Mi Majör'dür. Sol anahtarının kullanıldığı reklam müziği 4/4'lük basit dörtlü bir ölçüye sahiptir. Yapı olarak müzik eserinin içinde hem serbest ve hem ritmik bölümler bulunmaktadır. Müziğin temposu orta yavaş yani Andante (106 bmp)'dir. Akışın yumuşak olduğu ikili bir ritim kullanılmıştır.

Ziraat Bankası - "Senden vazgeçemem ben": Reklam filminin süresi $1 \mathrm{dk} .25$ saniyedir. Reklam müziğinin cıngıl ağırlıklı kullanımı söz konusudur. Rap müzik sanatçısı Yener Çevik'in "Vazgeç O Zaman" şarkısıyla başlayan reklam, 56. saniyeden sonra 1971 yılında Semiramis Pekkan tarafından seslendirilen "Senden vazgeçemem ben" şarkısının rap müzik türünde yeniden yorumlanması ve yine Yener Çevik tarafından seslendirilmesiyle devam etmektedir. Reklamın sloganı cıngıl olarak verilmektedir. Basit bir armonisi olan "Vazgeç o zaman” şarkısının tonu Re Minör'dür. Sol anahtarının kullanıldığı reklam müziği 9/8'lik aksak bir yapıya sahiptir. Müziğin temposu orta yavaş yani Andante (102 bmp)'dir. Akışın sert olduğu üçlü bir ritim kullanılmıștır. Yine basit bir armonisi olan "Senden vazgeçemem ben" şarkısının tonu La Minör'dür. Sol anahtarının kullanıldığı reklam müziği 9/8'lik aksak bir yapıya sahiptir. Müziğin temposu orta yavaş yani Andante (94 bmp)'dir. Akışın yumuşak olduğu üçlü bir ritim kullanılmıștır.

İş Bankası - "İş bankası 93 yaşında": Reklam filminin süresi 2 dk. 2 saniyedir. Reklamda cıngıl kullanılmamakta sadece fon müziğine yer verilmektedir. Fon müziği olarak reklam için hazırlanmış özgün bir yapıt kullanılmış dolayısıyla reklam müziği açısından ün veya ünlü kullanımına rastlanmamıștır. Oyuncu olarak Cem Yılmaz'ın rol aldığı reklam filminde kuraklık döneminde kasabası için çabalayan bir bakırcının hikayesi yine Cem Yılmaz tarafından masalsı bir tonda anlatılmaktadır. Reklamın sloganı fon müzik üzerine düz söz olarak verilmektedir. Kompleks bir armonisi olan müziğin tonu Re Majör'dür. Sol anahtarının kullanıldığı reklam müziği 3/4'lük basit dörtlü bir ölçüye sahiptir ve ritmik bir yapısı vardır. Müziğin temposu orta yavaş yani Andante (80 bmp)'dir. Akışın orta sert olduğu üçlü bir ritim kullanılmıştır.

Yapı Kredi - "Dünyanın en yenilikçi dijital bankası Yapı Kredi!": Reklam filminin süresi 51 saniyedir. Reklamda cıngıl kullanılmamakta sadece fon müziğine yer verilmektedir. Fon müziği olarak klasik batı müziği bestecisi George Friedrich Handel'in 11. süiti 
ya da yaygın bilinin adıyla Sarabande’si kullanılmıştır. Reklamın sloganı fon müzik üzerine düz söz olarak verilmektedir. Kompleks bir armonisi olan müziğin tonu Re Minör'dür. Sol anahtarının kullanıldığı reklam müziği, 3/2'lik basit ikili bir ölçüye sahiptir ve ritmik bir yapısı vardır. Müziğin temposu ağır yani Largetto (62 bmp)'dır. Akışın sert olduğu üçlü bir ritim kullanılmıștır.

Türkiye Halk Bankası - "Halk adını taşımak": Reklam filminin süresi $1 \mathrm{dk}$. 20 saniyedir. Reklamda cıngıl kullanılmamakta sadece fon müziğine yer verilmektedir. Fon müziği olarak Türk müziği besteci ve söz yazarı Melih Kibar'ın "Yadigar" şarkısı kullanılmıștır. Reklamın sloganı fon müzik üzerine düz söz olarak verilmektedir. Basit bir armonisi olan müziğin tonu Sol Minör'dür. Sol anahtarının kullanıldı reklam müziği 4/4'lük basit dörtlü bir ölçüye sahiptir. . Yapı olarak müzik eserinin içinde hem serbest ve hem ritmik bölümler bulunmaktadır. Müziğin temposu orta çabuk yani Moderato (112 bmp)'dur. Akışın yumuşak olduğu ikili bir ritim kullanılmıştır.

VakıfBank - "Yanındaki güç": Reklam filminin süresi 1 dk. 10 saniyedir. Reklamda cıngıl kullanılmamakta sadece fon müziğine yer verilmektedir. Fon müziği olarak reklam için hazırlanmış özgün bir yapıt kullanılmış dolayısıyla reklam müziği açısından ün veya ünlü kullanımına rastlanmamıştır. Reklam oyuncusu olarak Engin Altan Düzyatan'ın rol aldığı reklam filminde Vakıfbank'ın tüketicinin yanında olduğu yine Düzyatan tarafından anlatılmaktadır. Reklamın sloganı fon müzik üzerine düz söz olarak verilmektedir. Basit bir armonisi olan müziğin tonu Do Minör'dür. Sol anahtarının kullanıldı reklam müziği 12/8'lik ritmik bir yapıya sahiptir. Müziğin temposu orta çabuk yani Moderato (110 bmp)'dur. Akışın sert olduğu üçlü bir ritim kullanılmıştır.

DenizBank - "Denize çek gönder": Reklam filminin süresi 41 saniyedir. Reklam müziğinin fon ağırlıklı kullanımı söz konusudur. Sadece "Hayat deniz de güzel!" sloganı cıngıl olarak verilmektedir. Fon müziği olarak reklam için hazırlanmış özgün bir yapıt kullanılmış dolayısıyla reklam müziği açısından ün veya ünlü kullanımına rastlanmamıştır. Basit bir armonisi olan müziğin tonu Do Majör'dür. Sol anahtarının kullanıldı reklam müziği 4/4'lük basit dörtlü bir ölçüye sahiptir. . Yapı olarak müzik eserinin içinde hem serbest ve hem ritmik bölümler bulunmaktadır. Müziğin temposu orta yavaş yani Andante (100 bmp)'dir. Akışın sert olduğu ikili bir ritim kullanılmıştır.

Türkiye Ekonomi Bankası-TEB - “Marifetli hesap”: Reklam filminin süresi 40 saniyedir. Reklamda cıngll kullanılmamakta sadece fon müziğine yer verilmektedir. Fon müziği olarak reklam için hazırlanmış özgün bir yapıt kullanılmış dolayısıyla reklam müziği açısından ün veya ünlü kullanımına rastlanmamıştır. Basit bir armonisi olan müziğin tonu Sol Majör'dür. Sol anahtarının kullanıldığı reklam müziği, 4/4'lük basit dörtlü bir ölçüye sahiptir ve ritmik bir yapısı vardır. Müziğin temposu orta yavaş yani Andante (91 bmp)'dir. Akışın sert olduğu ikili bir ritim kullanılmıştır.

Ele alınan banka reklamların müzik yoluyla ikna edici iletişim açısından öne çıkan olumlu duyguların oluşmasını etkileyecek 10 temel kategoriye ilişkin çözümleme tablosu aşağıda yer aldığı şekildedir: 
Tablo 2: Reklam Müzikleri Çözümleme Tablosu

\begin{tabular}{|c|c|c|c|c|c|c|c|c|c|c|}
\hline & 言 & 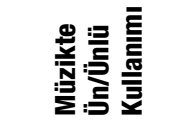 & 을 & : : & 稿 & 홀 & 产 & '高 & 焉 & 要 \\
\hline $\begin{array}{l}\text { Akbank } \\
\text { T.A.Ş. } \\
\text { "Telefonu } \\
\text { salla, kredini } \\
\text { gör anında" }\end{array}$ & Cingıl & $\begin{array}{l}\text { Athena } \\
\text { "Ah yaşamak } \\
\text { var ya" }\end{array}$ & $\begin{array}{c}\text { Allegro } \\
124-125 \\
\text { bmp }\end{array}$ & $\begin{array}{c}4 / 4 \\
\text { Basit } \\
\text { dörtlü }\end{array}$ & Ritmik & Sol & Minör & Basit & Tiz & Forte \\
\hline $\begin{array}{l}\text { Garanti } \\
\text { Bankası } \\
\text { "Herşey } \\
\text { bir hayalle } \\
\text { başlar" }\end{array}$ & Cingıl & $\begin{array}{c}\text { Nil } \\
\text { Karaibrahimgil } \\
\text { ve Mehmet } \\
\text { Erdem } \\
\text { "Herşey } \\
\text { bir hayalle } \\
\text { başlar" }\end{array}$ & $\begin{array}{l}\text { Andante } \\
106 \mathrm{bmp}\end{array}$ & $\begin{array}{c}4 / 4 \\
\text { Basit } \\
\text { dörtlü }\end{array}$ & $\begin{array}{c}\text { Serbest } \\
\text { ritmik + } \\
\text { ritmik }\end{array}$ & Sol & Majör & Basit & Orta & Piano \\
\hline \multirow{2}{*}{$\begin{array}{l}\text { Ziraat } \\
\text { Bankası } \\
\text { "Vazgeç o } \\
\text { zaman", } \\
\text { "Senden } \\
\text { vazgeçemem } \\
\text { ben" }\end{array}$} & \multirow[b]{2}{*}{ Cıngıl } & \multirow{2}{*}{$\begin{array}{l}\text { Yener Çevik } \\
\text { "Vazgeç o } \\
\text { zaman", } \\
\text { "Senden } \\
\text { Vazgeçemem } \\
\text { Ben" }\end{array}$} & $\begin{array}{l}\text { Andante } \\
102 \text { bmp }\end{array}$ & \multirow{2}{*}{$\begin{array}{c}\text { 9/8 } \\
\text { Bileşik } \\
\text { Üçlü }\end{array}$} & \multirow{2}{*}{ Aksak } & \multirow{2}{*}{ Sol } & \multirow{2}{*}{ Minör } & \multirow{2}{*}{ Basit } & \multirow{2}{*}{ Orta } & Forte \\
\hline & & & $\begin{array}{l}\text { Andante } \\
94 \text { bmp }\end{array}$ & & & & & & & Piano \\
\hline $\begin{array}{l}\text { İş Bankası } \\
\text { "İş Bankası } \\
93 \text { yaşında" }\end{array}$ & Fon & & $\begin{array}{l}\text { Andante } \\
80 \mathrm{bmp}\end{array}$ & $\begin{array}{c}3 / 4 \\
\text { Basit } \\
\text { dörtlü }\end{array}$ & Ritmik & Sol & Majör & Kompleks & Tiz & $\begin{array}{l}\text { Piano } \\
+ \\
\text { Forte }\end{array}$ \\
\hline $\begin{array}{l}\text { Yapı Kredi } \\
\text { Bankası } \\
\text { "Dünyanın } \\
\text { en yenilikçi } \\
\text { dijital bankası } \\
\text { Yapı Kredi" }\end{array}$ & Fon & $\begin{array}{l}\text { George } \\
\text { Friedrich } \\
\text { Handel } \\
\text { "11. Süit- } \\
\text { Sarabande" }\end{array}$ & $\begin{array}{l}\text { Largetto } \\
62 \mathrm{bmp}\end{array}$ & $\begin{array}{c}3 / 2 \\
\text { Basit } \\
\text { Ikili }\end{array}$ & Ritmik & Sol & Minör & Kompleks & Orta & Forte \\
\hline $\begin{array}{l}\text { Türkiye Halk } \\
\text { Bankası } \\
\text { "Halk adını } \\
\text { taşımak" }\end{array}$ & Fon & $\begin{array}{l}\text { Melih Kibar } \\
\text { "Yadigâr" }\end{array}$ & $\begin{array}{c}\text { Moderato } \\
112 \text { bmp }\end{array}$ & $\begin{array}{c}4 / 4 \\
\text { Basit } \\
\text { dörtlü }\end{array}$ & $\begin{array}{c}\text { Serbest } \\
\text { ritmik + } \\
\text { ritmik }\end{array}$ & Sol & Minör & Basit & Tiz & $\begin{array}{c}\text { Piano } \\
+ \\
\text { Forte }\end{array}$ \\
\hline $\begin{array}{l}\text { Vakıfbank } \\
\text { "Yanındaki } \\
\text { güç" }\end{array}$ & Fon & & $\begin{array}{l}\text { Moderato } \\
110 \mathrm{bmp}\end{array}$ & $\begin{array}{c}\text { 12/8 } \\
\text { Bileşik } \\
\text { dörtlü }\end{array}$ & Ritmik & Sol & Minör & Basit & Orta & Forte \\
\hline $\begin{array}{l}\text { Denizbank } \\
\text { "Denize çek } \\
\text { gönder" }\end{array}$ & $\begin{array}{l}\text { Fon }+ \\
\text { Cingıl }\end{array}$ & & $\begin{array}{l}\text { Andante } \\
100 \mathrm{bmp}\end{array}$ & $\begin{array}{c}4 / 4 \\
\text { Basit } \\
\text { dörtlü }\end{array}$ & $\begin{array}{c}\text { Serbest } \\
\text { ritmik + } \\
\text { ritmik }\end{array}$ & Sol & Majör & Basit & Orta & $\begin{array}{l}\text { Piano } \\
+ \\
\text { Forte }\end{array}$ \\
\hline $\begin{array}{l}\text { Türkiye } \\
\text { Ekonomi } \\
\text { Bankası } \\
\text { - TEB } \\
\text { "Marifetli } \\
\text { hesap" }\end{array}$ & Fon & & $\begin{array}{l}\text { Andante } \\
91 \mathrm{bmp}\end{array}$ & $\begin{array}{c}4 / 4 \\
\text { Basit } \\
\text { dörtlü }\end{array}$ & Ritmik & & Majör & Basit & Orta & Forte \\
\hline
\end{tabular}

\section{Sonuç}

İlk olarak sokak satıcılarının ürünlerini tanıtırken kullanmaya başladıkları reklamcılıkta müzik, insanlar üzerinde büyük bir etkiye sahiptir ve günümüzde markalar açısından çağrışım oluşturmaktan çok daha stratejik bir rol oynayarak reklamcılığın ayrılmaz bir parçası olarak karşımıza çıkmaktadır. Örneğin müzik tüketicilerle duygusal bir bağ kurarak satın alma kararlarında motive edici bir unsur olabilmektedir. Yapılan araştırmalar farklı müzik türlerinin insanlarda farklı tepkiler oluşturduğunu ortaya koymaktadır. $\mathrm{Bu}$ noktada markaların ürünleri için doğru müziği belirlemesi başka bir anlatımla hedef kitlelerde uyandırmak istedikleri duyguya uygun müzik türü hakkında bilgi sahibi olması gerekmektedir. Kısaca reklamcılıkta müziğin kullanımı önemlidir ama ikna edici iletişim stratejileri açısından doğru müziğin kullanımı çok daha önemlidir. 
$\mathrm{Bu}$ çalışmada içerik analiziyle yapılan incelemeye göre, araştırmaya konu olan reklamların hepsinde müziğe yer verildiği görülmektedir. 3 bankanın akılda kalıcılığı kolaylaştırmak için reklam metnini tamamen cıngıl yoluyla aktardığı, 5 bankanın reklam metnindeki sözlerin dramatik yapısına uygun fon müzikleri kullanılarak reklamın desteklendiği tespit edilmiştir. Bir bankanın ise sadece sloganı cıngıl olarak söylediği reklamın geri kalanında fon müzikten yaralandığı belirlenmiștir.

Reklam müzikleri ün/ ünlü kullanımı açısından ele alındığında, Akbank reklamında müzik grubu Athena'nın "Ah Yaşamak Var Ya” şarkısının -sözleri reklam mesajına uygun olacak şekilde- yeniden düzenlenerek sunulduğu, Garanti Bankası reklamında bestesi ve sözleri Nil Karaibrahimgil'e ait olan "Yalnız Değilsiniz" şarkısının, Nil Karaibrahimgil ve Mehmet Erdem birlikte seslendirildiği, Ziraat Bankası reklamının rap müzik sanatçısı Yener Çevik' in “Vazgeç O Zaman” şarkısıyla başladığı 56.saniyeden sonra ise 1971 yılında Semiramis Pekkan tarafından seslendirilen "Senden Vazgeçemem Ben" şarkısının rap müzik türünde yeniden yorumlanarak Yener Çevik tarafından seslendirildiği görülmektedir. Dünyanın En Değerli 500 Banka Markası - 2017 Türkiye listesinde ilk üç sırada yer alan ve reklam mesajlarını sadece cıngıl yoluyla aktaran bu bankaların reklam müziklerinde de ün/ ünlü kullanımlarına yer verdikleri ortaya konulmuştur. Ayrıca Yapı Kredi Bankası'nın fon müziği olarak klasik batı müziği bestecisi George Friedrich Handel'in 11. süiti ya da yaygın bilinin adıyla Sarabande'sini ve Türkiye Halk Bankası'nın fon müziği olarak Türk müziği besteci ve söz yazarı Melih Kibar'ın "Yadigar" şarkısı kullandıkları belirlenmiştir. Dolayısıyla ün/ünlü kullanımının bu bankalar için de geçerli olduğu görülmektedir. İş Bankası ve Vakıfbank reklam müziklerinde doğrudan bir ün/ünlü kullanımı yoktur. Fon müzikleri, bu reklamlar için özel olarak hazırlanmış özgün yapıtlardır. Fakat Huron $(1989,560)$, müziğin etkili bir reklama katkıda bulunabileceği temel yollardan birisi olarak yapı ve devamlılıktan bahsetmektedir. Müziğin en önemli yapısal rolünün öyküleyici dış sesleri veya ürün çekiciliklerini birbirine bağlaması olduğunu belirtmektedir. Bu, müzikte devamlılığın bir fonksiyonudur. Bu bilgiden yola çıkılarak İş Bankası reklamında fon müzik üzerindeki reklam metninin Cem Yılmaz tarafından ve Vakıfbank reklamında ise Engin Altan Düzyatan tarafından seslendirildiği dolayısıyla ün/ünlü kullanımına dolaylı olarak yer verildiğini, müzikte yapısal bağlayıcılığı ve devamlılığı sağlama fonksiyonunu yerine getirdiğini söylemek mümkündür. Denizbank ve Türkiye Ekonomi Bankası reklamları fon müzikleri özgündür, ün/ünlü kullanımına hiçbir şekilde yer verilmemiştir. Genellikle halk arasında yaygın olarak bilinen bir eserin farklı şekillerde (ritmik, armonik vs.) düzenlenerek tekrar gündeme getirilmesi veya reklam müziklerinin halk tarafından tanınan ünlü bir sanatçı tarafından söylenmesi reklamın dikkat çekiciliğini ve hatırda kalıcılığını artıran bir unsur olarak değerlendirilmektedir.

Araştırmaya konu olan bankaların reklam müzikleri tempo açısından incelendiğinde; Akbank ve Türkiye Halk Bankası reklam müziklerinin çeşitli araştırmalarda canlılık ve mutluluk hissi uyandırdığı belirlenen hızlı bir ölçüde sunulduğu, vuruş sayılarının 110'nun üzerinde olduğu saptanmıştır. Çalışmadaki diğer 6 bankanın vuruş sayıları Brumer $(1990,95)$ 'in belirtmiş olduğu ideal aralıkta yani 70-110 bpm aralığında yer almaktadır. Sadece Yapı Kredi Bankası'nın tempo hızının hüzün, can sıkıntısı vs. ifadelerle özdeşleşen 62 bmp yani yavaş ölçüde olduğu fakat "Üzülme be İsviçre...." sözleriyle başlayan reklamın içeriğinin aslında tempoyla uyum sağladığı görülmektedir. 
Araştırma kapsamında incelenen banka reklam müziklerinin beşinin 4/4'lük ve birinin 3/4'lük basit dörtlü ölçüde olduğu; Yapı Kredi Bankası reklam müziğinin 3/2'lik basit ikili, Vakıfbank reklam müziğinin 12/8'lik bileşik dörtlü ve Ziraat Bankası her iki reklam müziğinin 9/8'lik bileşik üçlü ölçüde olduğu görülmektedir. Bu durumda Ziraat Bankası reklamı hariç diğer bütün banka reklam müziklerinin aslında ikili ve ikinin katı olan dörtlü ölçüyü kullanmış oldukları belirlenmiştir. Descartes'in ikili ve dörtlü ölçülerin basit ifadelerden oluştuğu için "daha basit" duygular uyandırdığına ve Brumer $(1990,95)$ 'in ikili vuruşların, daha serbest ve coşkun olan üçlü vuruşlarla karşılaştırıldığında kontrollü bir ifade ürettiğine ilişkin görüşleri dikkate alındığında reklam müziklerinde ikili ve dörtlü basit ölçü kullanımının algılamaya ve sonrasında hatırlanabilirliğe katkı sağladığını söylemek mümkündür.

Ritim yapısı incelendiğinde Akbank, İş Bankası, Yapı Kredi Bankası, Vakıfbank ve Türkiye Ekonomi Bankası reklam müziklerinin pozitif bir algı uyandıran ritmik bir yapıda olduğu Garanti Bankası, Türkiye Halk Bankası ve Deniz Bank’ın ise daha karmaşık ifadeler üreten serbest ritmik yapıyla başlayan reklam müziklerinin yine ritmik bir yapıyla tamamlandığı belirlenmiștir. Ziraat Bankası reklamında ise; Yener Çevik tarafından seslendirilen "Vazgeç o zaman" ve "Senden vaz geçemem ben" parçalarının her ikisi de aksak olmakla birlikte ikisinde de kullanılan lirik dil reklamın duygusal çekiciliği artırmaktadır.

Nota anahtarı reklam müziklerinde duygusal ifadeler üreterek hedef kitleyi ikna etmenin aracı olarak kullanılan müziksel unsurlardan biridir. Araștırmada analiz edilen bankaların tamamının reklam müziklerinde daha mutluluk verici olduğu belirtilen yüksek anahtar yani sol anahtarını kullandıkları belirlenmiștir.

Müzik kalıbı açısından ele alındığında çeşitli araştırmalar genel olarak majör modu mutluluk ve sevinçle, minör modu ise daha çok üzüntüyle ilişkilendirmektedir. $\mathrm{Bu}$ çalışmada Garanti Bankası, İş Bankası, Deniz Bank ve Türkiye Ekonomi Bankası reklam müziklerinde majör modun kullanıldığı diğer beş bankanın reklam müziklerinde ise minör modun kullanıldığı görülmektedir. Ancak Gabrielsson ve Lindström $(2011,388)$, hangi ifadenin algılandığının genel durumla ilişkili olduğunu ileri sürmektedir. Örneğin, yüksek sesli akorlar ve yüksek perdeli akorlar, moddan bağımsız olarak yumuşak akorlardan ve düşük perdeli akorlardan daha fazla mutluluk hissi verebilir. Ayrıca, majör mod mutluluk algısı için gerekli bir şart değildir; hızlı tempo içindeki minör bir parça da kulağa çok hoş gelebilir. Bu bilgi doğrultusunda Akbank ve Türkiye Halk Bankası reklamlarının tiz yani yüksek perde de oldukları ayrıca tempolarının da hızlı olduğu başka bir ifadeyle minör moddan bağımsız olarak mutluluk hissi verebilecekleri belirlenmiștir.

Araştırmaya konu olan bankaların reklam müzikleri armoni açısından değerlendirildiğinde, sadece İş Bankası ve Yapı Kredi Bankası'nın ajite edici kompleks armoni kullandığı geri kalan yedi bankanın daha sakin ve mutluluk hissi veren basit armonilerden yararlandıkları görülmektedir. Kullanılan müziğin yapısı reklamın içeriğiyle de yakından ilgilidir. Kompleks armoni kullanan her iki bankanın reklam metinleri olumsuz bir durumum anlatımıyla başlayıp reklamın sonunda bu olumsuzluğun çözümü olarak kendi bankalarını göstermeleriyle tamamlanmaktadır. Dolayısıyla içeriğe bağlı olarak olumsuz hissiyatlar uyandıran kompleks armonilerin kullanılmasına karşın, her iki bankanın reklam müziklerinde 
ses perdesinin ve ses şiddetinin ikna ediciliği yüksek olumlu duygular uyandıran unsurlarla desteklendiği görülmektedir.

Sesin perdesi ile ilgili yapılan çalışmaların sonuçları çelişkili olmakla birlikte tiz seslerin insanlarda daha olumlu ve güçlü duygular uyandırdığı pes seslerin ise daha olumsuz duygusal ifadelerle eşleştiğini ortaya koymaktadır. Bu çalışmada İş Bankası, Akbank ve Türkiye Halk Bankası olmak üzere sadece üç bankanın tiz ses perdesinden yararlandığı diğer bankaların ise orta ses perdesi kullanmış oldukları görülmektedir.

Sesin şiddeti açısından ele alındığında yapılan araştırmalar fortenin heyecan verici pianonun ise sakinleştirici olduğunu ortaya koymaktadır. Yukarıdaki çözümleme tablosu incelendiğinde araştırmaya konu olan dört bankanın reklam müziklerinde heyecan verici duygular uyandıran fortenin kullanımına rastlanırken, üç bankanın ses şiddetinin sakinleştirici duygular uyandıran pianoyla başlayıp forteye yükseldiği görülmektedir. Sadece Ziraat Bankası'nın "Vazgeç o zaman" şarkısının forte "Senden vazgeçemem ben” şarkısının piano olduğu, Garanti Bankası'nın "Her şey bir hayalle başlar" reklamında ise sesin şiddeti pianoda sabit tutulduğu belirlenmiştir.

Sonuç olarak kurumlar reklam müzikleri yoluyla farklı hedef kitlelere aynı anda ulaşmaya çalışmaktadır. Müziğin duygular üzerindeki etkisinden dolayı yapımcılar reklam mesajlarını müzikle desteklemekte böylece reklamın etkinliğini, ürün ve hizmetlerin çekiciliğini artırmayı amaçlamaktadır. Reklamlarda müzik ikna edici iletişim stratejileri açısından en az diğer unsurlar kadar etkili ve önemlidir. Bu çalışmada “Dünyanın En Değerli 500 Banka Markası - 2017" listesinde yer alan dokuz Türk bankasının reklam film müzikleri; müziğin türü, müzik parçasının ya da seslendiren kişinin ünlü olup olması, temposu, ölçüsü, ritim yapısı, nota anahtarı, tonu, armonisi, müziğin perdesi ve sesin şiddeti açısından ele alınıp çözümlenmiştir. Bu çözümleme sonucunda elde edilen verilere göre, reklamlarda müziğin kullanımına ilişkin stratejilerin ikna stratejileriyle büyük ölçüde örtüştüğü sonucuna ulaşılmıştır. Dolayısıyla çalışmanın araştırma sorusu kabul edilmiştir. Başka bir anlatımla banka reklamlarında müzik duygulara hitap edebilmenin aracı olarak kullanılmakta ve doğru müzik unsurları kullanılarak ikna edici iletişim stratejilerinden etkin olarak yararlanılmaktadır.

\section{Notlar}

${ }^{1}$ Nota Anahtarı, portenin başına konan ve notaların hem adını, hem de müzik skalasındaki kesin yerini belirleyen işarettir. Üç tür anahtar vardır. Bunlar fa anahtarı, sol anahtarı ve do anahtarıdır. Her biri, başıadığı çizginin üzerindeki notaya kendi adını vermektedir (Baydu, 2016, 25).

${ }^{2}$ Armoni, seslerin birbiri ile uyumlu hareket etmelerini konu alan estetik yapının bütününe verilen isimdir (İmik, 2016, 22).

\section{Kaynakça}

Akbank T.A.Ş. (Yapımcı). (2018). Telefonunu Salla, Kredini Gör Anında [Reklam Filmi]. Türkiye: Akbank T.A.Ş. Erişim: 30 Ocak 2018, http://www.akbank.com/trtr/Yatirimci-iliskileri/Sayfalar/Reklamlar.aspx, https://www.youtube.com/ watch?v=mzaywPNZ2U8

Akgün, S. (2007). Reklam Müziğinin Marka Kişiliği Oluşumuna Katkısı: Bir Araştırma, Doktora Tezi, Marmara Üniversitesi, İstanbul. 
Allan, D. (2006). Effects of Popular Music in Advertising on Attention and Memory. Journal of Advertising Research, 46, 434-444.

Angı, Ç. (2013). Müzik Kavramı ve Türkiye'de Dinlenen Bazı Müzik Türleri. İdil Dergisi, 2 (10), 61.

Austin, M. (2014). Brand Image. W.F.Thompson (Ed.). Music in the Social and Behavioral Sciences: An Encyclopedia (p.155-156), SAGE Publications, Inc.

Babacan M. (2015), Nedir Bu Reklam?, İstanbul: Beta Yayınları

Baban, E. (2005). İkna Amaçlı Kitle İletişim Kuramlar ve Edward Bernays'ın Halkla İlişkiler Uygulamaları, Yüksek Lisans Tezi, Marmara Üniversitesi, İstanbul.

Balparmak’tan E- Bülten, 9 Şubat 2017, Sayı: 07. Erişim: 31 Aralık 2018, https:// www.balparmak.com.tr/images/files/BLP_E_BULTEN_07_09022017.pdf

Batı, U. (2010). Hedef kitle davranışını etkileyen bir unsur olarak reklamlarda müzik kullanımı konusundaki yazının incelenmesi. Uluslararası Insan Bilimleri Dergisi, 7 (2), 13.

Baydu, U. (2016). Müzik Terimleri Sözlüğ̈̈, İstanbul: Akıl Fikir Yayınları.

Brand Finance Banking 500 February 2017, The Annual Report on the World's Most Valuable Banking Brands, Erişim: 20 Ocak 2018, http://brandfinance.com/ images/upload/bf_banking_500_2017_locked.pdf

Bruner, G.C. (1990). Music, Mood, and Marketing. Journal of Marketing, 54 (4), 94104.

Büyüköztürk, Ş., Kılıç Çakmak, E., Akgün, Ö.E., Karadeniz, Ş. ve Demirel, F. (2008). Bilimsel Araştırma Yöntemleri, Ankara: Pegem Akademi.

Çelebioğlu, E. (2008). Müzik Kuramı. İstanbul: Bizim Kitaplar.

Collier, G.L., \& Hubbard, T.L. (2001). Judgments of happiness, brightness, speed and tempo change of auditory stimuli varying in pitch and tempo. Psychomusicology, 7, 36-55.

Coutinho, E., \& Cangelosi, A. (2009). The use of spatio-temporal connectionist models in psychological studies of musical emotions. Music Perception, 27, 1-15.

Dalla Bella, S. vd., (2001). A Developmental Study of the Affective Value of Tempo and Mode in Music, Cognition, 80 (3), 1-10.

Darıcı, S. (2013). Bilinçaltı Reklamcılık ve İletişim Teknikleri, İstanbul: İstanbul Gelişim Üniversitesi.

DenizBank (Yapımcı). (2018). Denize Çek Gönder [Reklam Filmi]. Türkiye: DenizBank. Erişim: 30 Ocak 2018, https://www.denizbank.com/hakkimizda/ reklamlarimiz-2017.aspx, https://www.youtube.com/watch?v=8jmg y2dQ4w

Dissmore,J.L. (2017). Baroque Music and the Doctrine of Affections: Putting the Affections into Effect, Cedarville University The Research and Scholarship Symposium 18, Erişim: 27 Mayıs 2018, http://digitalcommons.cedarville. edu/research_scholarship_symposium/2017/podium_presentations/18 
Eitan, Z., \& Timmers, R. (2010). Beethoven's last piano sonata and those who follow crocodiles: Cross-domain mappings of auditory pitch in a musical context. Cognition, 114, 405-422.

Elden M., Ulukök Ö. ve Yeygel S. (2015). Şimdi Reklamlar, İstanbul: İletişim Yayınları. Gabrielsson, A. (2008). The Relationship Between Musical Structure and Perceived Expression, S.Hallam, I.Cross ve M.Thaut (Ed.), The Oxford Handbook of Music Psychology (p.215-232), Oxford University Press.

Gabrielsson, A. ve Lindström, E. (2011).The Role of Structure in the Musical Expression, in P. N. Juslin ve J. Sloboda (Eds.), Handbook of Music and Emotion: Theory, Research, Applications (p.367-400), Oxford University Press.

Garanti Bankası (Yapımcı). (2018). Herşey Bir Hayalle Başlar [Reklam Filmi]. Türkiye: Garanti Bankası. Erişim: 30 Ocak 2018, https://www.garanti.com. $\mathrm{tr} / \mathrm{tr} /$ garanti_hakkinda/kurumsal-iletisim/videolarimiz.page, https://www. youtube.com/watch?v=hv5UnCg1lq4.

Genç, B. (2012). Metinlerarasılık Bağlamında Reklam-Müzik İlişkisi. Yüksek Lisans Tezi, Dokuz Eylül Üniversitesi, İzmir.

Gerçik, İ.Z.(2015). İletişim Psikolojisi: Dikta Değil İkna, 3.bsm. İstanbul: Küre Yayınları.

GSK-GlaxoSmithKline Consumer Healthcare, L.P (Yapımcı). Diş Hassasiyetine Karşı Uzmanlar Sensodyne'i Öneriyor [Reklam Filmi], Erişim: 31 Aralık 2018. https://www.youtube.com/watch?v=0vMXtvw-nDE

Gundlach, R.H. (1935). Factors determining the characterization of musical phrases. American Journal of Psychology, 47, 624-644.

Gülsoy. T. (1999). İngilizce - Türkçe Reklam Terimleri ve Kavramları Sözlügüu. İstanbul: Adam Yayınları.

Hagman, F. (2010). Emotional Response to Sound: Influence of Spatial Determinants, Master's Thesis in the Master's programme in Sound and Vibration, Chalmers University of Technology, Department of Civil and Environmental Engineering.

Hancock,B., Ockleford, E. ve Windridge, K. (2009). An Introduction to Qualitative Research, The NIHR RDS for the East Midlands / Yorkshire \& the Humber.

Hevner, K. (1937). The Affective Value of Pitch and Tempo in Music, The American Journal of Psychology, 49 (4), 621-630.

Hoeberichts, N. (2012). Music and Advertising: The Effect of Music in Television Commercials on Consumer Attitudes. Bachelor Thesis, Erasmus University Rotterdam Faculty of Economics and Business Marketing, Entrepreneurship, and Organization.

Huron, D. (1989). Music in Advertising: An Analytic Paradigm. The Musical Quarterly, 73 (4), 557-574.

İmik, Ü. (2016). Müzik ve Medya, Ankara: Gece Kitaplığı.

İplikçi, H.G. (2015). Reklamlarda Tüketiciyi İkna Etmek İçin Kullanılan Stratejiler Ve Reklam Örnekleri, Sosyal ve Beșeri Bilimleri Dergisi, 7 (1), 65-77. 
İş Bankası (Yapımcı). (2018). İş Bankası 93 Yaşında [Reklam Filmi]. Türkiye: İş Bankası. Erişim: 30 Ocak 2018, https://www.isbank.com.tr/TR/hakkimizda/ haberler-ve-medya/reklam-videolari/Sayfalar/reklam-videolari.aspx, https://www.youtube.com/watch?v=PCm2CsBcBPc

Jaquet, L., Danuser, B. ve Gomez, P. (2012). Music and Felt Emotions: How Systematic Pitch Level Variations Affect the Experience of Pleasantness and Arousal, Psychology of Music, 42 (1), 51-70.

Kaya, A. (2011). İletişime, Giriş: Temel Kavramlar ve Süreçler. A. Kaya (Ed.), Kişilerarası İlişkiler ve Etkili İletişim (ss.2-32), 2.bs. Ankara: Pegem Akademi.

Kellaris, J. J., Cox, A.D. ve Cox, D. (1993), The Effect of Background Music on Ad Processing: A Contingency Explanation, Journal of Marketing, 57 (4), 114-125.

Kleinen, G. (1968). Experimentelle Studien zum musikalischen Ausdruck [Experimental studies on musical expression]. Doctoral dissertation, Universität Hamburg, Germany.

Kutlay, E.B. (2007). Müziğin Bir Pazarlama Elementi Olarak Tüketici Üzerinde Duygusal, Algısal ve Davranışsal Etkileri, Doktora Tezi, İstanbul Üniversitesi, İstanbul.

Lindstrom, M. (2007). Duyular ve Marka: 5 Duyuyla Güçlü Markalar Yaratmak, İstanbul: Optimist Yayınları.

Madran, H. (2012). Tutum, Tutum Değişimi ve İkna, Ankara: Nobel Akademik Yayıncilık.

Metronom nedir?,Erişim: 04 Nisan 2018, http://www.muzikdunyasi.net/metronomnedir/

MEB - Milli Eğitim Bakanlığı (2011), Müzik Aletleri Yapımı: Müzik Işaretleri, Ankara: MEB Yayınları.

Okay, A. (2009). Kurumsal Reklamcılık. İstanbul: Derin Yayınları.

Özulu, İ. S. (1994). Reklamcllık ve Reklam Müziklerinin Radyo-Televizyondaki Yeri. İstanbul Üniversitesi, İstanbul.

Riley, D. ve Anderson, M. (2015) The Impact of Music Pleasantness and Fit on Advertising Attitudes for Low and High Involvement Consumers. In: Marketing and Business Development (MBD) International Conference 2015; 25-27 Jun 2015, Bucharest, Romania. ISSN (online) 2344-5130.

Shevy, M. Ve Hung,K. (2013). Music in Television Advertising and Other Persuasive Media. Siu-Lan Tan, Annabel Cohen, Scott Lipscomb, and Roger Kendall (Ed.), Psychology of Music in Multimedia (p. 315-338), Oxford: Oxford University Press,

Telman, N., ve Ünsal,P. (2009). İnsan İlişkilerinde İletişim. 2.bs. İstanbul: Epsilon Yayıncllık.

Tosun, N.B. (2003). Pazarlama Halkla İlişskileri ve Reklam: Bütünleşik Pazarlama İletişimi Yönlü Bir Yaklaşım, İstanbul: Türkmen Kitabevi.

Topsümer, F. ve Elden, M. (2015). Reklamcılık, Kavramlar, Kararlar, Kurumlar. İletişim Yayıncllık. 
Türkiye Ekonomi Bankası (Yapımcı). (2018). Marifetli Hesap [Reklam Filmi]. Türkiye: Türkiye Ekonomi Bankası. Erişim: 30 Ocak 2018, https://www. youtube.com/watch?v=qqXp9hZwjng

Türkiye Halk Bankası (Yapımcı). (2018). Halk Adını Taşımak [Reklam Filmi]. Türkiye: Türkiye Halk Bankası. Erişim: 30 Ocak 2018, https://www. halkbank.com.tr/13763-reklam_filmlerimiz, https://www.youtube.com/ watch?v=0zP8lFqNvtY

Uğur, İ. (2011). Televizyon Reklamlarında Müzik ve Reklam İlişkisi, Erciyes İletişim Dergisi “Akademia", 2 (1), 2-18.

VakıfBank (Yapımcı). (2018). Yanındaki Güç [Reklam Filmi]. Türkiye: Vakıf Bank. Erişim: 30 Ocak 2018, https://www.vakifbank.com.tr/vakifbankyanindaki-guc.aspx?pageID=2474vecmp=home, https://www.youtube.com/ watch?v=aJYZbS3z21I

Yapı Kredi Bankası (Yapımcı). (2018). Dünyanın En Yenilikçi Dijital Bankası Yapı Kredi [Reklam Filmi]. Türkiye: Yapı Kredi Bankası. Erişim: 30 Ocak 2018, https://www.yapikredi.com.tr/yapi-kredi-hakkinda/reklamlarimiz, https:// www.youtube.com/watch?v=niSjq6JbAZE

Yüksel, A. H. (2012). Tutum İkna ve İkna Edici İletişim. A.A.Bir (Ed.). İkna ve Konuşma (s.1-18), Eskişehir: Anadolu Üniversitesi Açık Öğretim Fakültesi Yayınları.

Watson, K.B. (1942). The nature and measurement of musical meanings. Psychological Monographs, 54, 1-43.

Wedin, L. (1972). Multidimensional scaling of emotional expression in music. Swedish Journal of Musicology, 54, 1-17.

Yıldırım, A. ve Şimşek, H. (2011). Sosyal bilimlerde nitel araştırma yöntemleri. Ankara: Seçkin Yayıncılık.

Ziraat Bankası (Yapımcı). (2018). Senden Vazgeçemem [Reklam Filmi]. Türkiye: Ziraat Bankası. Erişim: 30 Ocak 2018, https://www.ziraatbank.com.tr/tr/ Bankamiz/BasinOdasi/Pages/BankamizReklamFilmleri.aspx, https://www. youtube.com/watch?v=W72kfBe4Ido 